\title{
Effects of controlled pepsin hydrolysis on antioxidant potential and fractional changes of chickpea proteins
}

\author{
Iskender Arcan, Ahmet Yemenicioğlu* \\ Department of Food Engineering, Faculty of Engineering, Izmir Institute of Technology, 35430 Gülbahçe Köyü, Urla, İzmir, Turkey
}

\section{A R T I C L E I N F O}

\section{Article history:}

Received 23 June 2009

Accepted 7 September 2009

\section{Keywords:}

Antioxidant activity

Functional properties

Protein

Chickpea

Pepsin

Hydrolysate

Ultrafiltration

\begin{abstract}
A B S T R A C T
This study investigated the effects of controlled pepsin hydrolysis on antioxidant potential and fractional changes of chickpea protein extracts (CPE). The enzyme hydrolysis increased soluble protein content (1.2 to 2 -fold) and free radical scavenging activity (1.9 to 3-fold) of hydrolyzed chickpea protein extract (HCPE), but almost unaffected its antioxidant potential in oil-in-water emulsion system and reduced its iron chelating capacity (1.3-fold) and functional properties. The chromatographic fractions of CPE are mainly acidic, while those of HCPE are mainly basic and neutral. The majority of chickpea proteins had pI between 4.5 and 5.5, and molecular weight (MW) between 15 and $40 \mathrm{kDa}$, while MW of their pepsin hydrolysis products ranged between 6.5 and $14.2 \mathrm{kDa}$. The main antioxidant proteins in CPE and HCPE fractionated by ultrafiltration had MW greater than $30 \mathrm{kDa}$ and between 2 and $10 \mathrm{kDa}$, respectively. The chickpea proteins and hydrolysates showed different potentials as functional food ingredients.
\end{abstract}

(c) 2009 Elsevier Ltd. All rights reserved.

\section{Introduction}

In different food systems, proteins are used as ingredients due to their nutritive value and functional properties such as emulsifying activity, foam and gel formation, oil, water and flavor binding, increase of viscosity etc. (Damodaran, 1996). Different proteins including plant origin proteins from legumes and cereals, and animal origin proteins from whey, egg white, fish processing waste etc. have also been reported to possess antioxidant activity (Chiue, Kusano, \& Iwami, 1997; Hu, McClements, \& Decker, 2003; Je, Park, \& Kim, 2005; Rajalakshmi \& Narasimhan, 1996). The proteins owe their antioxidant activity to their constituent amino acids such as aromatic, sulfur containing and basic amino acids which are capable to donate protons to free radicals (Hu et al., 2003; Je et al., 2005; Rajapakse, Mendis, Jung, Je, \& Kim, 2005). The basic and acidic amino acids also have ability of chelating metal ions that are responsible for initiation of lipid oxidation in foods (Je et al., 2005; Rajapakse et al., 2005). The cationic characteristics of proteins also help electrostatic repulsion of metal atoms away from the lipid droplets (Chiue et al., 1997; Hu et al., 2003), whereas surface active characteristics enable binding and burying of unsaturated lipids (Chiue et al., 1997; Rajapakse et al., 2005).

The functional properties including antioxidant activity have been studied most extensively for soybean and milk proteins (Chove, Grandison, \& Lewis, 2007; Hu et al., 2003; Le Tien, Vachon,

\footnotetext{
* Corresponding author. Tel.: +90 232 7506292; fax: +90 2327506196 .

E-mail address: ahmetyemenicioglu@iyte.edu.tr (A. Yemenicioğlu).
}

Mateescu, \& Lacroix, 2001; Tong, Sasaki, McClements, \& Decker, 2000; Webb, Naeem, \& Schmidt, 2002). Different studies have also been conducted to improve functional properties of these proteins by enzymatic hydrolysis (Chen, Muramoto, \& Yamauchi, 1995; Pacheco, Amaya-Farfan, \& Sgarbieri, 2002; Penas, Prestamo, \& Gomez, 2004). Thus, the commercial applications in food industry have been limited mostly to soybean and milk proteins. Recently, the increased demand to plant based proteins as food ingredients has also encouraged studies on functionality of proteins from soybean alternative legumes such as chickpeas, common beans, lentils, cowpeas, lupins, peas and broad beans (Bamdad, Goli, \& Kadivar, 2006; Horax, Hettiarachchy, Chen, \& Jalaluddin, 2004; Makri, Papalamprou, \& Doxastakis, 2005; Morales-De Leon, Vazquez-Mata, Torres, Gil-Zenteno, \& Bressani, 2007; Sanchez-Vioque, Clemente, Vioque, Bautista, \& Millan, 1999). However, there are very limited studies related to antioxidant activity of soybean alternative legume proteins. These studies are related to antioxidant activities of water soluble albumin proteins of broad beans, white and brown beans and light peas (Okada \& Okada, 1998; Wolosiak \& Klepacka, 2002). Recently, for the first time in the literature, we have showed the antioxidant potential and thermal stability of chickpea proteins containing heavily albumin fraction (Arcan \& Yemenicioğlu, 2007). Then, Li, Jiang, Zhang, Mu, and Liu (2008) hydrolyzed chickpea globulins by alcalase and characterized the antioxidant and molecular properties of these hydrolysates. In this study, we applied controlled pepsin hydrolysis of chickpea protein extracts containing both albumins and globulins based on maximization of free radical scavenging activity and sol- 
uble protein content, and characterized the antioxidant potential, major functional properties and fractional changes in chickpea proteins modified by hydrolysis. The chickpeas having high protein quality and low amounts of toxic and antinutritive factors are good source of functional proteins (Freidman, 1996; Hernandez-Infante, Sousa, Montalvo, \& Tena, 1998). This study makes a contribution to the current trend of developing alternative sources of proteins to increase functionality and nutritional value of foods.

\section{Materials and methods}

\subsection{Materials}

Dry chickpeas (Cicer arietinum $L$.) were purchased from a supermarket in Izmir (Turkey). DEAE-cellulose (fast flow) and ABTS (2,2Azino-bis-(3-Ethylbenz-Thiazoline-6-Sulfonic acid) diammonium salt) were purchased from Sigma Chem. Co. (St. Louis, Mo., USA). Toyopearl sulphopropyl (SP) (SP-550C, fast flow) was obtained from Supelco (Bellefonte, PA, USA). Commercial whey protein isolate (WPI, Protein content: 97.8\%) was kindly donated by Davisco Foods International, INC (MN, USA).

\subsection{Extraction of proteins}

To remove phenolic compounds and lipids, acetone powders (AP) prepared as described by Arcan and Yemenicioğlu (2007) were used as source of protein extracts. To obtain crude protein extracts, $4 \mathrm{~g}$ of AP was suspended in $120 \mathrm{ml}$ deionized water. The $\mathrm{pH}$ of the mixture was adjusted to 9.5 with $0.1 \mathrm{~N} \mathrm{NaOH}$ and its total volume was brought to $130 \mathrm{ml}$ with deionized water. The protein extracts of chickpeas obtained at this $\mathrm{pH}$ contain both albumin and globulin protein fractions (Makri et al., 2005). For inactivation of oxidative enzymes such as lipoxygenase (and to stop pepsin action at the end of enzyme hydrolysis given in Section 2.3), the extract was then heated to $85^{\circ} \mathrm{C}$ and maintained at this temperature for 30 min under continuous magnetic stirring. After that, the extract was cooled to room temperature and further extracted for 30 min by magnetic stirring. The $\mathrm{pH}$ of the extract was then adjusted to 7.0 with $0.1 \mathrm{~N}$ acetic acid and its final volume was made up to $150 \mathrm{ml}$ with deionized water. The extract was clarified by centrifugation for $30 \mathrm{~min}$ at $15000 \mathrm{~g}$ and $4{ }^{\circ} \mathrm{C}$ and incubated overnight at $4{ }^{\circ} \mathrm{C}$ to precipitate insolubilized materials such as starch and starch-protein complexes. At the end of incubation period the extract was once more clarified by centrifugation for $15 \mathrm{~min}$ at $4500 \mathrm{~g}\left(4^{\circ} \mathrm{C}\right)$. The chickpea protein extract (CPE) obtained by this method was directly used in column chromatography or lyophilized and stored at $-18^{\circ} \mathrm{C}$ for further test of antioxidant potential, pI and/or SDS-PAGE patterns.

\subsection{Preparation of protein hydrolysates}

To obtain the hydrolyzed chickpea protein extract (HCPE), $4 \mathrm{~g}$ AP was suspended in $100 \mathrm{ml}$ of deionized water. The $\mathrm{pH}$ of the suspension was adjusted to 2.5 with $0.5 \mathrm{~N} \mathrm{HCl}$ solution and $134 \mathrm{mg}$ pepsin (34 mg pepsin per $\mathrm{g}$ AP) was added to medium (The optimal amount of enzyme used in protein hydrolysis was determined at smaller scale experiments conducted by suspending $2 \mathrm{~g}$ AP in $50 \mathrm{ml}$ deionized water). The suspension was incubated at $37^{\circ} \mathrm{C}$ for $24 \mathrm{~h}$ under continuous shaking at $150 \mathrm{rpm}$ and its $\mathrm{pH}$ was adjusted to 9.5 with $0.5 \mathrm{~N} \mathrm{NaOH}$ at the end of the incubation period. The total volume of the extract was then brought to $130 \mathrm{ml}$ with deionized water, and after heating at $85{ }^{\circ} \mathrm{C}$ for $30 \mathrm{~min}$ the extraction was continued exactly as described for CPE in Section 2.2.

\subsection{Fractionation with ion-exchange chromatography}

For this purpose, $50 \mathrm{ml}$ of CPE or HCPE was loaded onto a DEAEcellulose anion exchange column (CPE also fractionated with Toyopearl SP-550C (TP-SP) cation exchange column at the same conditions) $(2.4 \mathrm{~cm}$ diameter, $10.0 \mathrm{~cm}$ height) previously equilibrated with $0.01 \mathrm{M}$, Na-phosphate buffer at $\mathrm{pH}$ 7.0. The washing of the column was conducted by $200-250 \mathrm{ml}$ of the equilibration buffer and the column was then eluted with a continuous linear gradient of $0-1 \mathrm{M} \mathrm{NaCl}$ prepared in $0.01 \mathrm{M}, \mathrm{Na}$-phosphate buffer at $\mathrm{pH} 7.0$. Fractions $(5 \mathrm{ml})$ collected from the column were assayed for their free radical scavenging activity against ABTS radical cation, and absorbance at $280 \mathrm{~nm}$ for monitoring of protein concentration.

\subsection{Fractionation with ultrafiltration}

The CPE and HCPE was fractionated by using a laboratory scale cross-flow ultrafiltration (UF) device (Sartorius Model Slice 200, Goettingen, Germany) equipped with Hydrosart ${ }^{\circledR}$ membranes having cut-off values of 30,10 or $2 \mathrm{kDa}$. $100 \mathrm{ml}$ of CPE or HCPE was first UF treated trough the $30 \mathrm{kDa}$ membrane. The retentate $\left(\mathrm{R}_{1}\right.$ or $\left.\mathrm{r}_{1}\right)$ and permeate fractions $\left(\mathrm{P}_{1}\right.$ or $\left.\mathrm{p}_{1}\right)$ were collected separately and then the permeates were diluted to $100 \mathrm{ml}$ and UF treated trough the $10 \mathrm{kDa}$ membrane (capital letters for CPE, small letters for HCPE fractions). The retantates $\left(R_{2}\right.$ or $\left.r_{2}\right)$ and permeates $\left(P_{2}\right.$ or $\left.p_{2}\right)$ were once more collected and a final UF was applied to permeates (after once more diluted to $100 \mathrm{ml}$ ) by using a $2 \mathrm{kDa}$ membrane to obtain the other fractions $\left(P_{3}, p_{3}, R_{3}, r_{3}\right)$. All fractions were assayed for their free radical scavenging activity and protein content.

\subsection{SDS-PAGE and 2-D electrophoresis of proteins}

The classical SDS-PAGE of CPE and HCPE were conducted on a discontinuous buffered system according to Laemmli method (Dunn, 1989) using 15\% separating gel and 5\% stacking gel. Lyophilized samples were directly solubilized in sample buffer and centrifuged at $15000 \mathrm{~g}$ for $30 \mathrm{~min}$. The samples were then heated for $5 \mathrm{~min}$ in boiling water before electrophoresis. The electrophoresis was performed at a constant current of $12 \mathrm{~mA}$. Protein fixation was performed with TCA (20\%). The gel was stained with $50 \%$ methanol, $10 \%$ acetic acid, $0.05 \%$ Coomassie brilliant blue (R-250) solution. The gel destaining was accomplished by using $5 \%$ methanol and $12.5 \%$ acetic acid solution. Wide molecular weight range molecular marker was used to characterize the obtained protein bands (SigmaMarker ${ }^{\mathrm{TM}}$, Sigma-Aldrich).

The two dimensional (2-D) electrophoresis (isoelectric focusing and SDS-PAGE) was applied to CPE with the ReadyPrep ${ }^{\mathrm{TM}}$ 2-D Starter Kit (BioRad Laboratories Inc.) according to product instructions manual. The sample was prepared in deionized water and then diluted with sample buffer. IPG Strips (ReadyStrip ${ }^{\mathrm{TM}}$, BioRad), $17 \mathrm{~cm}$ and $\mathrm{pH} 3-10$, were used for isoelectric focusing (IEF). IEF was applied using the Protean IEF cell (BioRad) with three step voltage protocol: $250 \mathrm{~V}$ for $20 \mathrm{~min}$ (linear ramp), $10,000 \mathrm{~V}$ for $2.5 \mathrm{~h}$ (linear ramp), and total $40,000 \mathrm{~V} \times \mathrm{h}$ rapid ramp step. SDS-PAGE was performed at a two step constant current protocol: $16 \mathrm{~mA} /$ gel for $30 \mathrm{~min}$, then $24 \mathrm{~mA} /$ gel for $5 \mathrm{~h}$ in $12 \%$ SDS gel with PROTEAN II $\mathrm{XL}$ (BioRad). The protein fixation, staining and destaining was performed as given in the classical SDS-PAGE method given above. Protein Ladder, 10-200 kDa (Fermentas International, Inc.) and 2D SDS-PAGE standard, pI range 4.5-8.5, (BioRad) were used as marker.

\subsection{Free radical scavenging activity}

The free radical scavenging activity was determined against ABTS free radical cation (Re et al., 1999). The reaction mixture of 
chromatographic or UF fractions were formed by mixing $0.1 \mathrm{ml}$ protein solution and $1.9 \mathrm{ml}$ ABTS free radical solution. The discoloration of dark blue colored ABTS radical by the antioxidant protein was monitored at $734 \mathrm{~nm}$ and \% inhibition of the free radical was calculated at the end of 2 or 15 min test periods for determination of trolox equivalents of chromatographic and UF fractions, respectively. The free radical scavenging capacities of lyophilized protein extracts were determined with the more detailed Area Under the Curve (AUC) method (Re et al., 1999). The lyophilized samples were dissolved in deionized water and clarified by centrifugation at $15000 \mathrm{~g}$ for $30 \mathrm{~min}$ at $4{ }^{\circ} \mathrm{C}$. Different volumes (7.5, 15 and $25 \mu \mathrm{l})$ of protein solution were then mixed with $1.9 \mathrm{ml}$ ABTS radical solution. At each volume, the tests were conducted for three times. The test periods to calculate the AUC values were $1,3,6,9,12,15 \mathrm{~min}$. The results were expressed as $\mu \mathrm{mol}$ Trolox/g lyophilized powder. In this test and in $\mathrm{Fe}^{+2}$ chelating capacity and inhibition of lipid oxidation test commercial WPI was used as a reference to compare antioxidant potential of chickpea proteins.

\section{8. $\mathrm{Fe}^{+2}$ chelating capacity}

The $\mathrm{Fe}^{+2}$ chelating capacity of protein extracts were determined as described in Rajapakse et al. (2005) with minor modifications. Briefly, $2 \mathrm{ml}$ lyophilized protein solubilized in deionized water was mixed with $0.1 \mathrm{ml}, 1 \mathrm{mM} \mathrm{FeCl}_{2}$ solution. After 30 min incubation at room temperature, $0.1 \mathrm{ml}, 5 \mathrm{mM}$ ferrozine was added into mixture and its absorbance was read at $562 \mathrm{~nm}$ after $10 \mathrm{~min}$ incubation. The percent $\mathrm{Fe}^{+2}$ chelating capacities of samples were determined by using deionized water in place of sample. The $\mathrm{Fe}^{+2}$ chelating capacity was determined by dividing the slope of the initial linear portion of $\mathrm{Fe}^{+2}$ chelating activity (\%) vs. concentration curves with that slope of the same curve of the chelating agent disodium EDTA. The results were expressed as $\mu$ mol EDTA per $g$ of lyophilized powder. All measurements were performed in triplicate.

\subsection{Inhibition of lipid oxidation}

The inhibition of lipid oxidation by lyophilized protein extracts was tested in an oil-in-water emulsion system at $60^{\circ} \mathrm{C}$. The emulsion system contains $20 \% \mathrm{w} / \mathrm{w}$ commercial olive oil, $1 \% \mathrm{w} / \mathrm{w}$ protein, $0.5 \% \mathrm{w} / \mathrm{w}$ Tween-20, and $0.04 \% \mathrm{w} / \mathrm{w}$ sodium azide. The emulsion was obtained with a disperser-homogenizer (Heidolph, Germany, stator diameter: $8.2 \mathrm{~mm}$, rotor diameter : $6.6 \mathrm{~mm}$ ) at $20,000 \mathrm{rpm}$ in $5 \mathrm{~min}$. Each emulsion was transferred into $50-\mathrm{ml}$ dark-colored Erlenmeyer flask, flasks were sealed tightly and placed in a shaking incubator at $60{ }^{\circ} \mathrm{C}$ to start the oxidation experiment. The lipid oxidation was monitored by the spectrophotometric thiobarbituric acid-reactive substances (TBARS) assay performed at $532 \mathrm{~nm}$ as described by Tong et al. (2000). The results were given by subtracting the absorbance values determined after some time from the initial absorbance value $\left(\mathrm{Abs}_{\mathrm{t}}-\mathrm{Abs}_{0}\right)$. The test of each protein was conducted by using two samples and assaying these samples for three times.

\subsection{Functional properties}

Emulsification properties of lyophilized proteins were determined by the method described in Pearce and Kinsella (1978). For this purpose, $20 \mathrm{ml}$ of $1 \%$ CPE or HCPE (prepared in distilled water and $\mathrm{pH}$ was adjusted to 7.0) was mixed with $6.5 \mathrm{ml}$ of commercial olive oil and emulsified by homogenization at 22,000 rpm for $2 \mathrm{~min}$ in a homogenizer-disperser (Yellowline, DI 18 Basic, Brazil, diameters of stator: $10 \mathrm{~mm}$ and rotor: $7.5 \mathrm{~mm}$ ). A $200 \mu \mathrm{l}$ of the emulsion was then mixed with $25 \mathrm{ml}$ of SDS (1\%) solution. The emulsifying activity was determined by measuring sample turbidity as NTU units with a HACH turbidimeter (2100 AN, the USA). The emulsion stability was determined by monitoring of turbidity after 30 and $180 \mathrm{~min}$ of emulsification. The tests were repeated for two times.

To determine the foaming properties, $20 \mathrm{ml}$ of $1 \%$ CPE or HCPE solution ( $\mathrm{pH} 7.0$ ) was placed into a $50 \mathrm{ml}$ standard disposable centrifuge tube (Falcon, diameter: $30 \mathrm{~mm}$, height: $120 \mathrm{~mm}$ ) and homogenized with the disperser-homogenizer at $22,000 \mathrm{rpm}$ for $1 \mathrm{~min}$ to induce foaming. The foaming activity was determined by measuring the volume of the formed foam immediately. The foam stability was determined by monitoring foam volume after $30,60,180$ and $360 \mathrm{~min}$ of foam formation. The tests were repeated for two times.

\subsection{Protein content}

The protein content of lyophilized samples (dissolved in deionized water and clarified by centrifugation at $15000 \mathrm{~g}$ for $30 \mathrm{~min}$ at $4{ }^{\circ} \mathrm{C}$ ) and pooled chromatographic fractions were determined by the Lowry method by using bovine serum albumin (BSA) as standard (Harris, 1987). The average of five measurements was used to calculate the protein content.

\section{Results and discussion}

\subsection{Controlled pepsin hydrolysis}

In this study, controlled pepsin hydrolysis applied was based on increase of soluble protein content and free radical scavenging activity of chickpea proteins. To determine optimal hydrolysis conditions, APs were hydrolyzed by different amounts of pepsin. As seen in Fig. 1, use of 17 or $34 \mathrm{mg}$ pepsin/g AP during extraction increased free radical scavenging activity and protein content in extracts almost 3 and 1.5-2-fold, respectively. Pepsin concentrations over $17 \mathrm{mg} / \mathrm{g}$ AP caused slight to moderate reductions in free radical scavenging activity of hydrolyzed chickpea protein extract (HCPE). The highest soluble protein content was achieved by hydrolysis at $34 \mathrm{mg}$ pepsin/g AP, but protein content reduced continuously as pepsin concentration got higher. This was the indication of extensive hydrolysis of protein peptide bonds and reduced detection by the Lowry method. The extensive enzymatic hydrolysis of proteins is not suggested since this caused loss of functional properties and formation of bitter peptides in the hydrolysates (Chabanon, Chevalot, Framboisier, Chenu, \& Marc, 2007; Davidek, Velisek, \& Pokorny, 1990; Kong, Zhou, \& Qian 2007). Therefore,

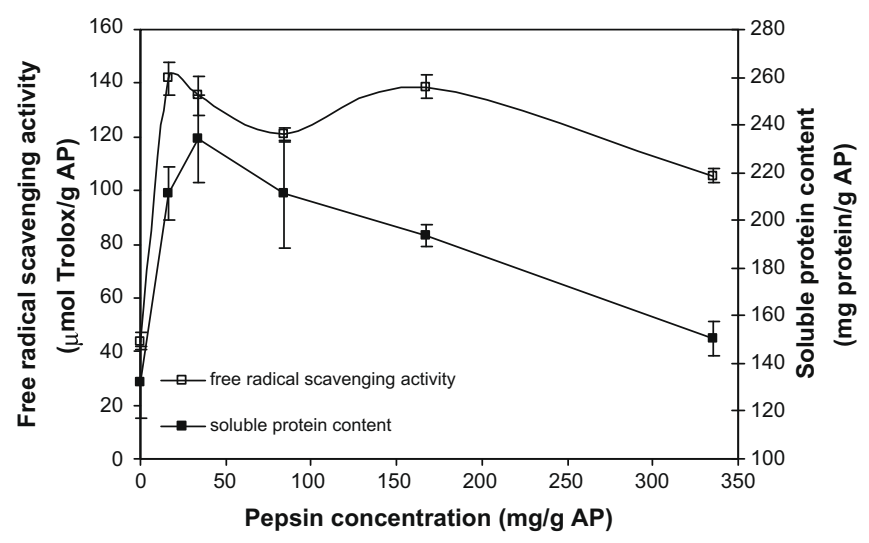

Fig. 1. Effect of pepsin concentration on free radical scavenging activity and protein content of chickpea protein extract. 
Table 1

Free radical scavenging and iron binding capacity of lyophilized chickpea protein extracts and commercial whey protein isolate.

\begin{tabular}{llll}
\hline Sample & $\begin{array}{l}\text { Soluble protein } \\
\text { content }(\mathrm{g} \\
\text { protein/g } \\
\text { powder) }\end{array}$ & $\begin{array}{l}\text { Free radical scavenging } \\
\text { capacity }^{\mathrm{a}}(\mu \mathrm{mol} \\
\text { Trolox/g powder })\end{array}$ & $\begin{array}{l}\text { Iron chelating } \\
\text { capacity }(\mu \mathrm{mol} \\
\left.\mathrm{Na}_{2} \text { EDTA/g powder }\right)\end{array}$ \\
\hline CPE & $0.34 \pm 0.011$ & $143 \pm 4.0$ & 156 \\
HCPE & $0.39 \pm 0.039$ & $277 \pm 10.0$ & 122 \\
WPI & $0.94 \pm 0.048$ & $101 \pm 9.0$ & 21 \\
\hline
\end{tabular}

${ }^{a}$ AUC value.

hydrolysis was performed by using $34 \mathrm{mg}$ pepsin per g of AP used in this study.

\subsection{Effect of pepsin hydrolysis on antioxidant potential}

The antioxidant potentials of lyophilized CPE and HCPE were compared to each other and with that of commercial whey protein isolate (WPI) based on free radical scavenging capacity, iron binding capacity and inhibition of oxidation in oil-in-water emulsion system (Table 1 ). The WPI forms a reference to better understand the antioxidant properties of chickpea proteins due to its well known antioxidant potential (Hu et al., 2003; Le Tien et al., 2001; Tong et al., 2000). As expected, the free radical scavenging capacity of lyophilized HCPE is almost 1.9-fold higher than that of CPE. However, the CPE showed 1.3-fold higher iron binding capacity than HCPE. This result indicated some limited destruction in proteins' iron binding domains or groups by pepsin treatment. Both CPE and HCPE showed 1.4 and 2.7-fold higher free radical scavenging capacity, and 5.8 and 7.4-fold higher iron binding capacity than WPI, respectively. However, the results of inhibition tests for olive oil oxidation in emulsion system contradicted with these results. The WPI inhibited the oxidation of olive oil minimum 46 days, while CPE and HCPE inhibited oxidation of this oil for almost 25 days (Fig. 2). It appears that the higher performance of WPI in oil-in-water emulsion system is related to its 2.4 and 2.8-fold higher protein content than CPE and HCPE, respectively. It is likely that the WPI formed a thicker film layer than chickpea proteins around olive oil globules and showed more protective effect against their oxidation. It is also interesting to note the slightly higher antioxidant activity of CPE in oil-in-water emulsion system than HCPE which showed higher free radical scavenging activity and soluble protein content than CPE. This suggested greater surface active properties of CPE than the HCPE and its greater interaction and protective effect on olive oil globules. The overall results of antiox-

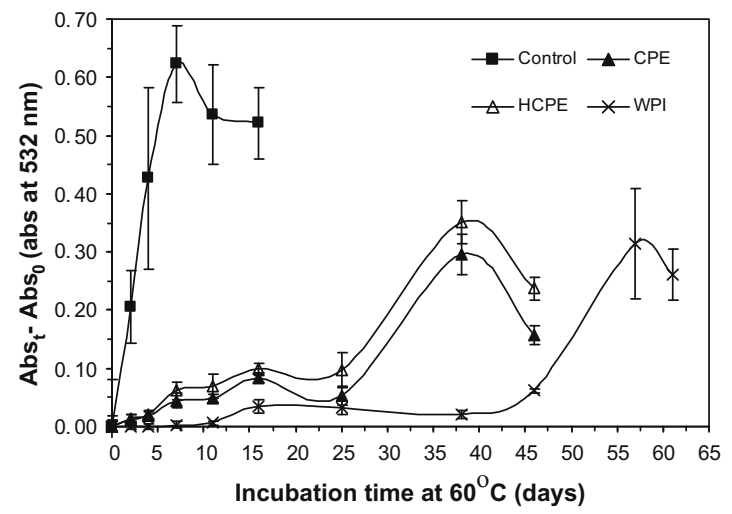

Fig. 2. Antioxidant activity of different protein extracts in olive oil-in-water emulsion system.

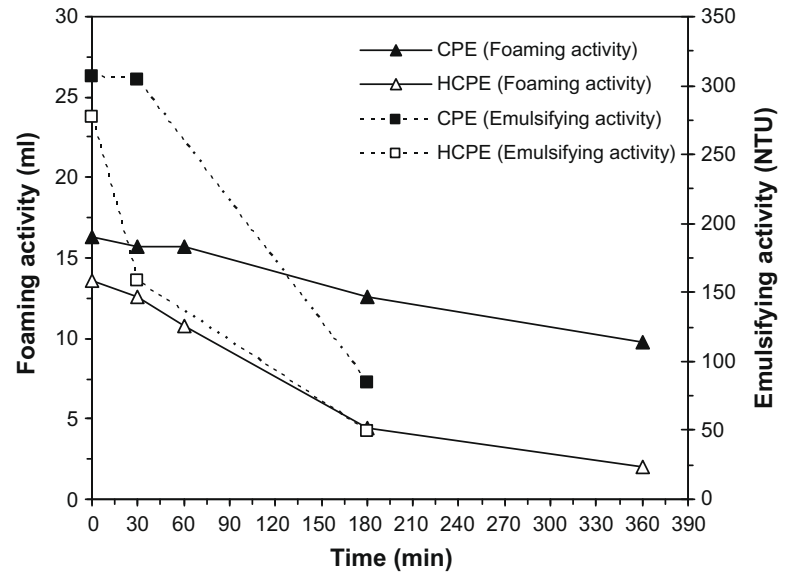

Fig. 3. Effect of pepsin treatment on emulsification and foaming properties of chickpea proteins.

idant potential tests indicated a considerable increase of free radical scavenging activity of chickpea proteins by the pepsin treatment, while causing a slight and a moderate reduction in their antioxidant activity in oil-in-water emulsion system and iron binding capacity, respectively.

\subsection{Effect of pepsin hydrolysis on major functional properties}

To better evaluate the effect of controlled pepsin treatment on technological value of chickpea proteins, the CPE and HCPE were also characterized for their emulsifying and foaming properties. As seen in Fig. 3, the CPE and HCPE showed similar initial foaming and emulsifying activities. However, the emulsions and foams formed by CPE showed considerably higher stabilities than those of HCPE. Thus, it appears that the pepsin treatment based on increasing protein content and free radical scavenging activity reduced the surface active properties and resulting functional properties of chickpea proteins. These data supported our hypothesis that the lack of improvement in antioxidant activity of pepsin hydrolyzed chickpea proteins in oil-in-water emulsion system is due to their reduced surface activity. In the literature, different effects of enzymatic hydrolysis were reported in functional properties depending on degree of protein hydrolysis. For example, Kong et al. (2007) reported increased foam and emulsion stability of wheat gluten by very limited enzymatic hydrolysis. The gained foaming stability partly maintained by increased enzymatic hydrolysis, but this caused reduction of emulsion stability below initial level. Chabanon et al. (2007) reported an increased emulsion stability of albumin and globulin protein fractions from rapeseeds by limited enzymatic hydrolysis, but reduced emulsion stability of these fractions at high degree of enzymatic hydrolysis. The rapeseed albumin fraction lost its foaming stability by low or high degree of enzymatic hydrolysis, while foaming stability of globulin fraction improved at both conditions. These studies clearly showed the complexity of finding an optimal enzyme treatment to improve overall technological properties of a protein. Further studies are needed to understand the detailed effects of pepsin treatment on functional properties of chickpea proteins.

\subsection{Effect of pepsin hydrolysis on chromatographic fractions}

The chromatogram of CPE based on free radical scavenging activity showed the presence of two DEAE-unbound (basic + neutral) (A-1, A-2), and two DEAE-bound (acidic) antioxidant fractions (A-3, A-4) (Fig. 4). The sum of free radical scavenging activities for 


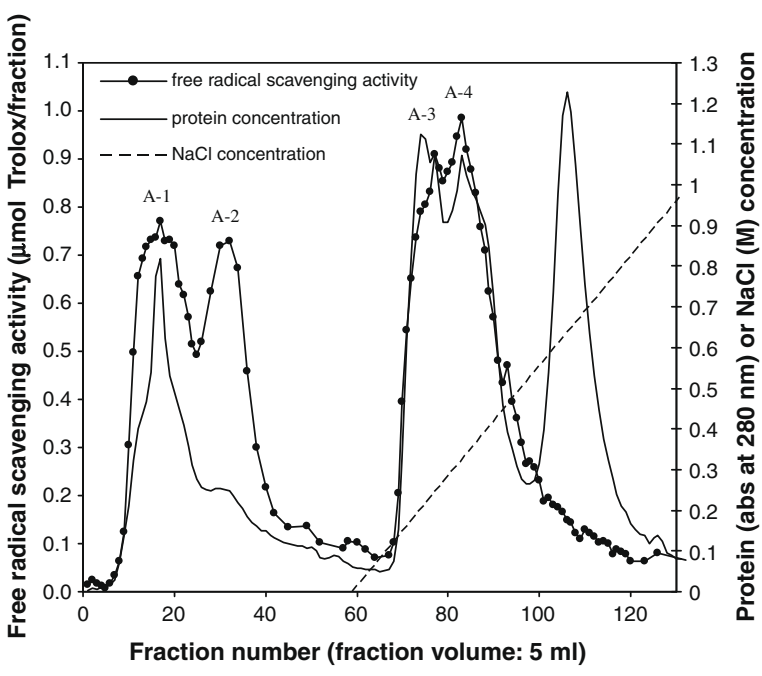

Fig. 4. Fractionation of chickpea protein extract by DEAE-cellulose chromatography.

eluted fractions of acidic proteins $(26.2 \mu \mathrm{mol}$ Trolox from fraction 59 to 130) formed almost $56 \%$ of that for all eluted proteins from the column ( $47.1 \mu \mathrm{mol}$ Trolox from fraction 1 to 130$)$. The pooled acidic antioxidant fractions of $\mathrm{CPE}$ also had higher protein content than its basic and neutral fractions (A-1, A-2, A-3, A-4 contained 14.4, 8.7, 40.7, $68.5 \mathrm{mg}$ protein, respectively). The Toyopearl-SP cation-exchange chromatography of CPE yielded one DEAE-unbound (acidic + neutral) and one DEAE-bound (basic) protein fraction for free radical scavenging activity (results were not given). The sum of free radical scavenging activities for eluted fractions of basic proteins formed almost $28 \%$ of that for all eluted fractions. These results clearly showed the greater contribution of acidic proteins than the basic ones in free radical scavenging activity and protein content of CPE.

The DEAE-cellulose chromatography of HCPE was also given in Fig. 5. The pepsin treatment did not change the number of antioxidant protein fractions extracted at $\mathrm{pH}$ 9.5. $\mathrm{H}-1$ and $\mathrm{H}-2$ are basic and neutral, and $\mathrm{H}-3$ and $\mathrm{H}-4$ are acidic antioxidant protein fractions. The sum of free radical scavenging activities of eluted acidic protein fractions for HCPE (31.5 $\mu \mathrm{mol}$ Trolox from fraction no 71158) and CPE were not considerably different. However, the sum of

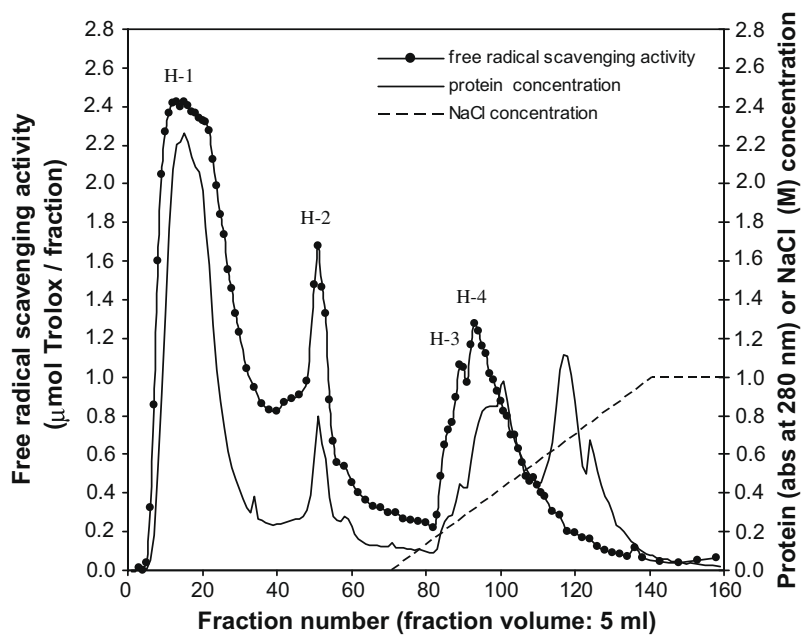

Fig. 5. Fractionation of pepsin hydrolyzed chickpea protein extract by DEAEcellulose chromatography. free radical scavenging activities of eluted basic and neutral protein fractions for HCPE $(80.2 \mu \mathrm{mol}$ Trolox $)$ was almost 4-fold higher than that for CPE (20.9 $\mu$ mol Trolox). The protein contents of pooled antioxidant fractions of HCPE clearly showed the increased extraction of basic and neutral protein fractions by the enzyme treatment $(\mathrm{H}-1, \mathrm{H}-2, \mathrm{H}-3, \mathrm{H}-4$ contained $244,19.8,18.9,36.0 \mathrm{mg}$ protein, respectively).

\subsection{Effect of pepsin hydrolysis on ultrafiltration fractions}

To understand the ranges of molecular weights for antioxidant chickpea proteins, CPE and HCPE were fractionated by ultrafiltration (UF) using different membranes. The UF of CPE from a $30 \mathrm{kDa}$ membrane resulted with retention of almost $91 \%$ and $64 \%$ of its protein content and free radical scavenging activity in the retentate $\left(R_{1}\right)$, respectively (Fig. $6 A$ and $B$ ). Only, 3\% of protein and $17 \%$ of free radical scavenging activity of CPE passed through $30 \mathrm{kDa}$ membrane as permeate $\left(\mathrm{P}_{1}\right)$, while remaining residual protein (almost 6\%) could not be detected due to possible aggregation in the concentrated retentate or adsorption by the membrane. On the other hand, $33 \%$ of protein content and $24 \%$ of free radical scavenging activity of HCPE remained at the retentate $\left(r_{1}\right)$ of $30 \mathrm{kDa}$ membrane during UF treatment. Almost half of the HCPE's protein content and more than half of the resulting free radical scavenging
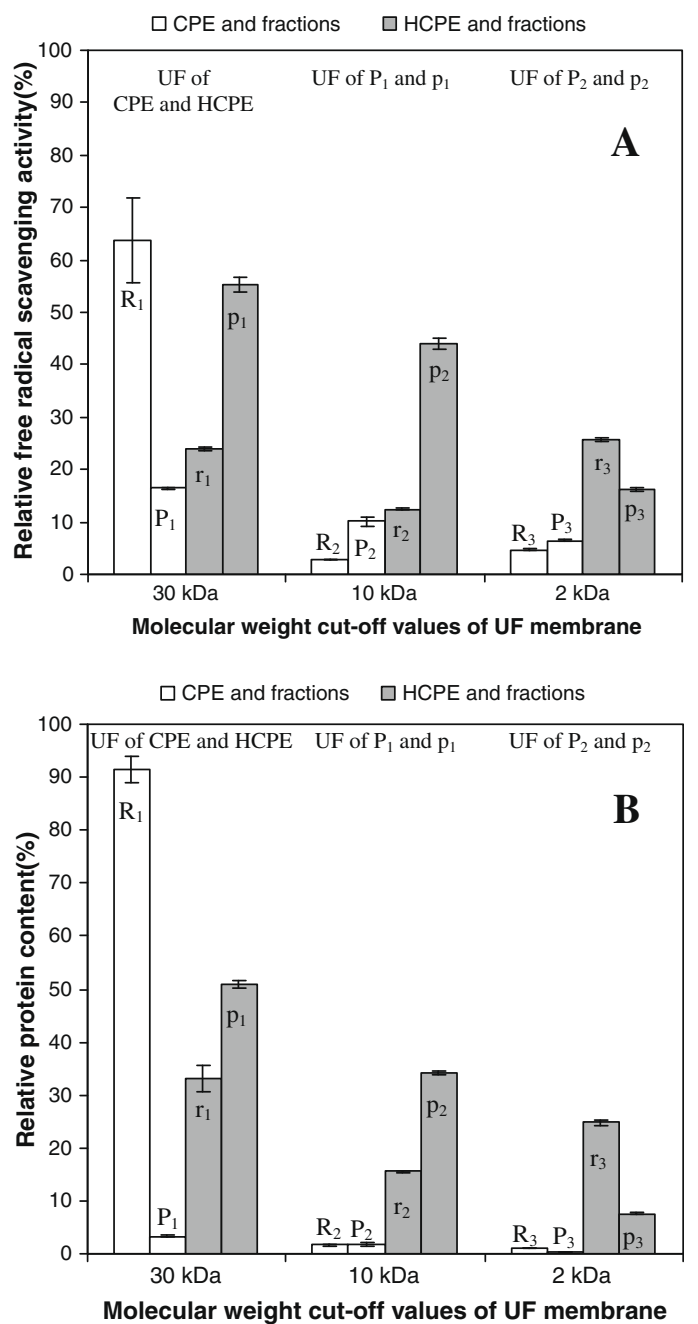

Fig. 6. Fractionation of chickpea protein extracts by ultrafiltration (free radical scavenging activity and soluble protein content of CPE and HCPE were 100\%). 


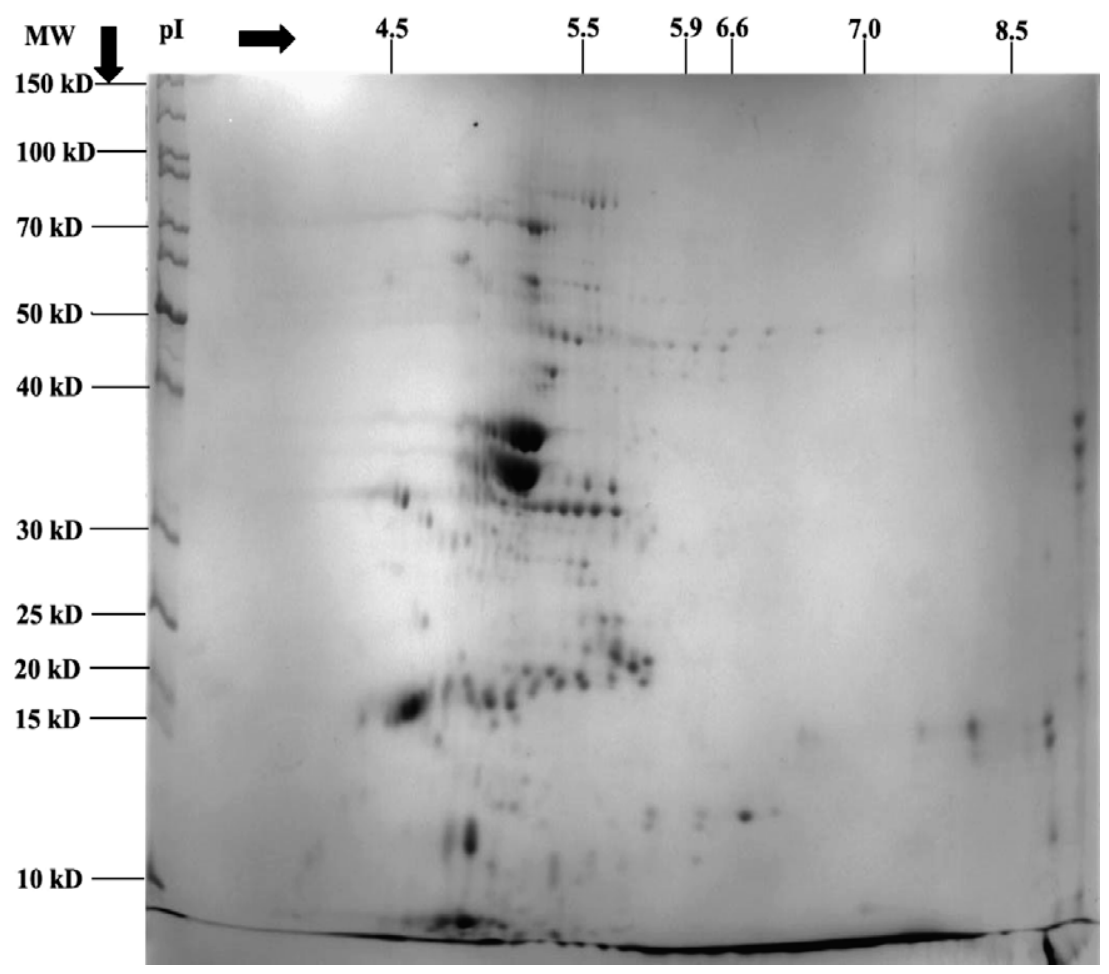

Fig. 7. 2-D SDS-PAGE of chickpea protein extract.

activity passed through the $30 \mathrm{kDa}$ membrane and collected as permeate $\left(p_{1}\right)$. However, more protein loss occurred during UF of HCPE than the CPE. In the second cycle, permeates from $30 \mathrm{kDa}$ $\left(\mathrm{P}_{1}\right.$ and $\left.\mathrm{p}_{1}\right)$ were UF treated in $10 \mathrm{kDa}$ membrane, and then in the third cycle, permeates $\left(\mathrm{P}_{2}\right.$ and $\left.\mathrm{p}_{2}\right)$ from $10 \mathrm{kDa}$ were UF treated in $2 \mathrm{kDa}$ membrane. These additional UF cycles did not provide a considerable data for CPE since very little amounts of proteins passed through the $30 \mathrm{kDa}$ membrane. However, the results ob- tained for HCPE clearly showed the reduced MW ranges of proteins by pepsin treatment. Almost $35 \%$ of protein and $40 \%$ of free radical scavenging activity of HCPE passed through the $10 \mathrm{kDa}$ membrane. The $2 \mathrm{kDa}$ membrane retained most of the protein in permeate from $10 \mathrm{kDa}$ membrane $\left(\mathrm{p}_{2}\right)$. The free radical scavenging activity of proteins in permeate of $2 \mathrm{kDa}$ membrane $\left(\mathrm{p}_{3}\right)$ corresponded almost to $7 \%$ of free radical scavenging activity of HCPE. Therefore, it is clear that the majority of antioxidant proteins of HCPE had

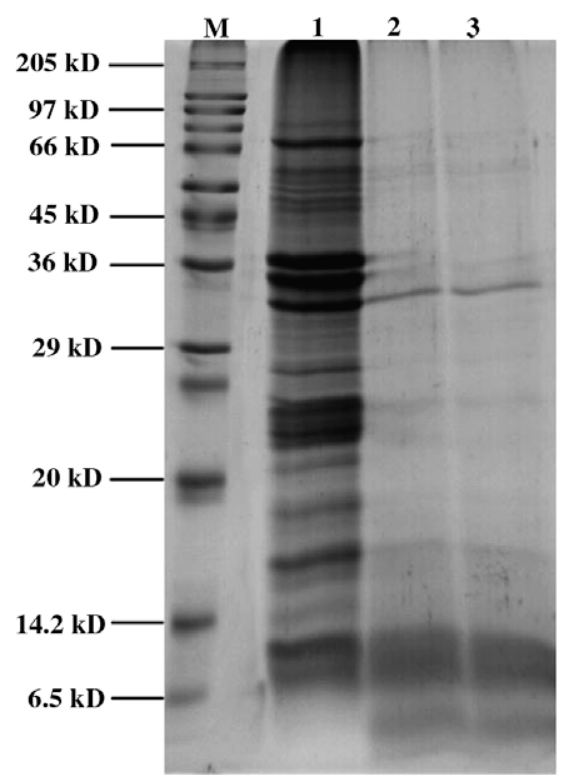

A

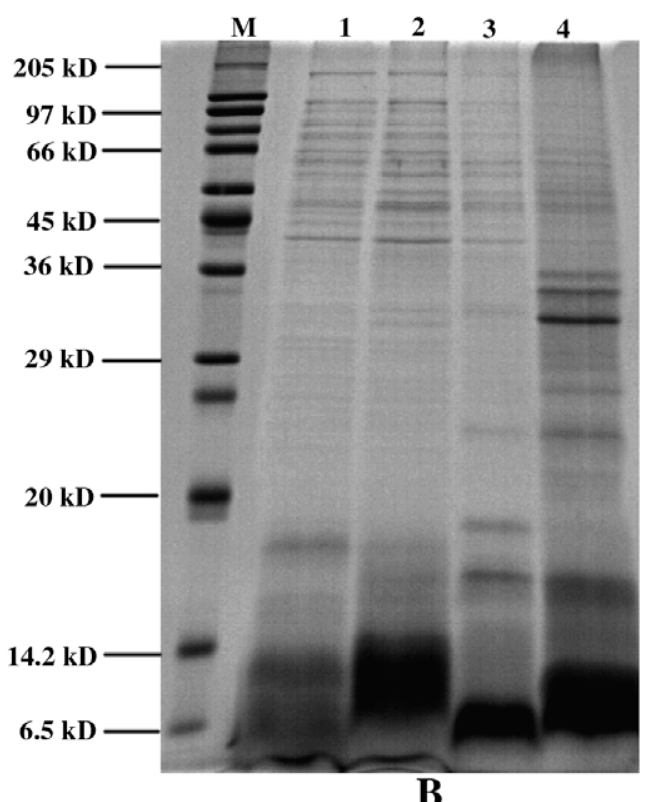

Fig. 8. SDS-PAGE profiles of chickpea protein extracts and pepsin hydrolysates (M: MW markers; In A: 1: CPE; 2: HCPE (hydrolyzed by 17 mg pepsin/g AP); 3 : HCPE (hydrolyzed by 34 mg pepsin/g AP); In B: 1: H-1; 2: H-2; 3 : H-3; 4: H-4). 
MW between 2 and $10 \mathrm{kDa}$, while there is also some certain antioxidant protein residues remained between 10 and $30 \mathrm{kDa}$ and above $30 \mathrm{kDa}$.

\subsection{SDS-PAGE and 2-D electrophoresis of proteins}

The 2-D electrophoresis of CPE indicated that majority of the chickpea proteins have pI between 4.5 and 5.5 (Fig. 7). The molecular weigh profiles obtained from SDS-PAGE step of 2-D for CPE also suggested the distribution of most of the chickpea proteins between 15 and $25 \mathrm{kDa}$ and 30 and $40 \mathrm{kDa}$. The classical SDS-PAGE of CPE also yielded 10-11 intense bands with molecular weights of $71 \mathrm{kDa}, 37-33 \mathrm{kDa}$ (3 bands), 23-22 kDa (3-4 bands), $18 \mathrm{kDa}$ and $13-8 \mathrm{kDa}$ ( 2 bands) (line 1 in Fig. 8A). The SDS-PAGE of HCPEs suggested that the pepsin treatment caused considerable hydrolysis of chickpea proteins having molecular weight above $14 \mathrm{kDa}$ (lines 2 and 3 in Fig. 8A). The only dense band appeared in HCPE above $14 \mathrm{kDa}$ and resisted to pepsin action was a $34 \mathrm{kDa}$ protein. The other protein bands of HCPE formed densely between 8 and $13.5 \mathrm{kDa}$, but weakly below $6.5 \mathrm{kDa}$. It was reported that chickpea allergenic proteins appear on SDS-PAGE between 23 and $25 \mathrm{kDa}$ (Clemente, Vioque, Sanchez-Vioque, Pedroche, \& Millan, 1999; Vioque et al., 1998). In this study, some protein bands have been observed between 21 and $23 \mathrm{kDa}$ for CPE. These bands could not be detected clearly for different HCPEs, but they appeared in the DEAE-cellulose chromatographic HCPE fraction of H-4. The chromatographic fractions contained proteins in more pure and concentrated form and this improved monitoring of the hydrolyzed protein bands after pepsin action (lines 1-4 in Fig. 8B). The SDSPAGE patterns of $\mathrm{H}-1, \mathrm{H}-2, \mathrm{H}-3$ and $\mathrm{H}-4$ confirmed that the major products of enzymatic hydrolysis were proteins at molecular weight range between 6.5 and $14.2 \mathrm{kDa}$. The $\mathrm{H}-1$ and $\mathrm{H}-2$ fractions also contained some high MW protein residues appeared between 40 and $180 \mathrm{kDa}$.

In conclusion, the controlled pepsin hydrolysis can successfully be used to increase the free radical scavenging activity and soluble protein content of chickpea proteins. The antioxidant activity of pepsin hydrolyzed proteins in oil-in-water emulsion system is also comparable with that of unhydrolyzed chickpea proteins. On the other hand, the enzyme treatment reduced the antioxidant activity based on iron chelating capacity, and emulsion and foam stability which are related to surface activity. The crude chickpea protein extracts and pepsin hydrolysates showed considerably higher free radical scavenging and iron binding capacity, but lower antioxidant activity in oil-in-water emulsions than the highly pure commercial whey protein isolate. The high surface activity and resulting emulsion and foam stability of unhydrolyzed chickpea proteins showed the good potential of these proteins as technologically functional food additives. The pepsin hydrolysates of chickpea proteins may be useful to increase free radical scavenging based antioxidant activity, solubility and digestibility of these proteins for nutritive purposes. The chickpea proteins can be used as crude extracts, or purified, concentrated or fractionated by the characterized chromatographic or ultrafiltration methods for some more specific applications.

\section{Acknowledgement}

This project was funded by the Research Foundation of Izmir Institute of Technology (IYTE) (Project \# 2004 IYTE 05). We appreciate the IYTE Biotechnology and Bioengineering Central Research Laboratories for providing the 2D electrophoresis system. We thank Davisco Foods International for providing the WPI used in this study and Research Assistant Levent Y. Aydemir for his kind assistance during determination of protein functional properties.

\section{References}

Arcan, I., \& Yemenicioğlu, A. (2007). Antioxidant activity of protein extracts from heat treated or thermally processed chickpeas and white beans. Food Chemistry, $103,301-312$.

Bamdad, F., Goli, A. H., \& Kadivar, M. (2006). Preparation and characterization of proteinous film from lentil (Lens culinaris). Food Research International, 39, 106-111.

Chabanon, G., Chevalot, I., Framboisier, X., Chenu, S., \& Marc, I. (2007). Hydrolysis of rapeseed protein isolates: Kinetics, characterization and functional properties of hydrolysates. Process Biochemistry, 42, 1419-1428.

Chen, H., Muramoto, K., \& Yamauchi, F. (1995). Structural analysis of antioxidative peptides from soybean $\beta$-conglycinin. Journal of Agricultural and Food Chemistry, 43, 574-578.

Chiue, H., Kusano, T., \& Iwami, K. (1997). Deamidation-induced fragmentation of maize zein, and its linked reduction in fatty acid-binding capacity as well as antioxidative effect. Food Chemistry, 58, 111-117.

Chove, B. E., Grandison, A. S., \& Lewis, M. J. (2007). Some functional properties of fractionated soy protein isolates obtained by microfiltration. Food Hydrocolloids, $21,1379-1388$

Clemente, A., Vioque, J., Sanchez-Vioque, R., Pedroche, J., \& Millan, F. (1999) Production of extensive chickpea (Cicer arietinum L.) protein hydrolysates with reduced antigenic activity. Journal of Agricultural and Food Chemistry, 47, 3776-3781.

Damodaran, S. (1996). Amino acids, peptides and proteins. In O. R. Fennema (Ed.), Food chemistry (pp. 321-430). New York: Marcel Decker Inc.

Davidek, J., Velisek, J., \& Pokorny, J. (1990). Chemical changes during food processing. New York: Elsevier [pp. 17-24].

Dunn, M. J. (1989). Electrophoretic analysis methods. In E. L. V. Haris \& S. Angal (Eds.), Protein purification methods: A practical approach (pp. 18-40). New York: Oxford University Pres Inc.

Freidman, M. (1996). Nutritional value of proteins from different food sources. A review. Journal of Agricultural and Food Chemistry, 44, 6-29.

Harris, D. A. (1987). Spectrophotometric assays. In D. A. Harris \& C. L. Bashford (Eds.), Spectrophotometry and spectrofluorometry (pp. 59-60). Oxford: I.R.L. Press.

Hernandez-Infante, M., Sousa, V., Montalvo, I., \& Tena, E. (1998). Impact of microwave heating on hemagglutinins, tyripsin inhibitors and protein quality of selected legume seeds. Plant Foods for Human Nutrition, 52 199-208.

Horax, R., Hettiarachchy, N. S., Chen, P., \& Jalaluddin, M. (2004). Preparation and characterization of protein isolate from Cowpea (Vigna unguiculata L. Walp.). Journal of Food Science, 69, 114-118.

Hu, M., McClements, D. J., \& Decker, E. A. (2003). Lipid oxidation in corn oil-in-water emulsions stabilized by casein, whey protein isolate, and soy protein isolate. Journal of Agricultural and Food Chemistry, 51, 1696-1700.

Je, J., Park, P., \& Kim, S. (2005). Antioxidant activity of a peptide isolated from alaska pollack (Theragra chalcogramma) frame protein hydrolysate. Food Research International, 38, 45-50.

Kong, X., Zhou, H., \& Qian, H. (2007). Enzymatic preparation and functinal properties of wheat gluten hydrolysates. Food Chemistry, 101, 615-620.

Le Tien, C., Vachon, C., Mateescu, M. A., \& Lacroix, M. (2001). Milk protein coatings prevent oxidative browning of apples and potatoes. Journal of Food Science, 66 512-516.

Li, Y., Jiang, B., Zhang, T., Mu, W., \& Liu, J. (2008). Antioxidant and free radicalscavenging activities of chickpea protein hydrolysate (CPH). Food Chemistry, 106, 444-450.

Makri, E., Papalamprou, E., \& Doxastakis, G. (2005). Study of functional properties of seed storage proteins from indigenous European legume crops (lupin, pea, broad bean) in admixture with polysaccharides. Food Hydrocolloids, 19, 583-594.

Morales-De Leon, J., Vazquez-Mata, N., Torres, N., Gil-Zenteno, L., \& Bressani, R. (2007). Preparation and characterization of protein isolate from fresh and hardened beans (Phaseolus vulgaris L.). Journal of Food Science, 72 96-102.

Okada, Y., \& Okada, M. (1998). Scavenging effect of water soluble proteins in broad beans on free radicals and active oxygen spices. Journal of Agricultural and Food Chemistry, 46, 401-406.

Pacheco, M. T. B., Amaya-Farfan, J., \& Sgarbieri, V. C. (2002). Partial characterization of a whey protein concentrate and its enzyme hydrolysates. Journal of Food Biochemistry, 26, 327-338.

Pearce, K. N., \& Kinsella, J. E. (1978). Emulsifying properties of proteins-evaluation of a turbidimetric technique. Journal of Agricultural and Food Chemistry, 26, 716-723.

Penas, E., Prestamo, G., \& Gomez, R. (2004). High pressure and the enzymatic hydrolysis of soybean whey proteins. Food Chemistry, 85, 641-648.

Rajalakshmi, D., \& Narasimhan, S. (1996). Food antioxidants: Sources and methods of evaluation. In D. L. Madhavi, S. S. Deshpande, \& D. K. Salunke (Eds.), Food antioxidants (pp. 65-158). New York: Marcel Dekker, Inc.

Rajapakse, N., Mendis, E., Jung, W., Je, J., \& Kim, S. (2005). Purification of a radical scavenging peptide from fermented mussel sauce and its antioxidant properties. Food Research International, 38, 175-182.

Re, R., Pellegrini, N., Proteggente, A., Pannala, A., Yang, M., \& Rice-Evans, C. (1999) Antioxidant activity applying an improved ABTS radical cation decolorization assay. Free Radical Biology E' Medicine, 26, 1231-1237. 
Sanchez-Vioque, R., Clemente, A., Vioque, J., Bautista, J., \& Millan, F. (1999). Protein isolates from chickpea (Cicer arientinum L.): Chemical composition, functional properties and protein characterization. Food Chemistry, 64, 237-243.

Tong, L. M., Sasaki, S., McClements, D. J., \& Decker, E. A. (2000). Mechanisms of the antioxidant activity of a high molecular weight fraction of whey. Journal of Agricultural and Food Chemistry, 48, 1473-1478.

Vioque, J., Clemente, A., Sanchez-Vioque, R., Pedroche, J., Bautista, J., \& Millan, F. (1998). Comparative study of chickpea and pea Pa2 albumins. Journal of Agricultural and Food Chemistry, 46, 3609-3613.
Webb, M. F., Naeem, H. A., \& Schmidt, K. A. (2002). Food protein functionality in a liquid system: A comparison of deamidated wheat protein with dairy and soy proteins. Journal of Food Science, 67, 2896-2901.

Wolosiak, R., \& Klepacka, M. (2002). Antioxidative properties of albumins in enzymatically catalyzed model systems. Electronic Journal of Polish Agricultural Universities, Series: Food Science and Technology, 5, 1. <http:// www.eipau.media.pl>. 